OPEN ACCESS

\title{
The Role of Economic Cluster Perspectives in Regional Economic Development
}

\author{
Robert Haak, ${ }^{1}$ Gautam Vora, ${ }^{2}$ Steven T. Walsh, ${ }^{3 *}$ and Craig G. White ${ }^{4}$

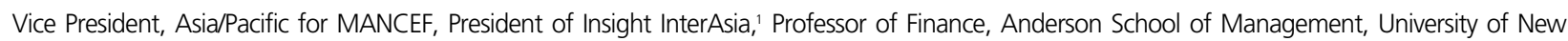 \\ Mexico, ${ }^{2}$ Distinguished and Regents Professor, Anderson School of Management, University of New Mexico, Institute Professor of Entrepreneurial \\ Renewal of Industry at Nikos University of Twente, ${ }^{3}$ Grant Thornton Professor of Accounting, Accounting Department Chair, Anderson School of \\ Management, University of New Mexico ${ }^{4}$
}

\begin{abstract}
The importance of science and technology as the root of exceptional regional economic development has been extolled since the time of Schumpeter. Today emerging technologies are signaling the start of a new economic cycle where regions that are effective in technology translation will gain advantage. The will of policymakers to translate technology into regional job and wealth creation seems to be at an all-time high. Yet an improved process for translating technical development into regional prosperity has proved elusive. If there are no processes other than applying techniques that have worked in the past for other regions to a new region then there is cause for concern.

Here the authors seek to add to this field of knowledge by applying elements of the varied cluster theories to provide a basis for policy for regional economic development by turning science and technology into commercial innovation. We provide a review of current cluster theories and discuss the positive and negative issues associated with each. We propose a model that allows interested professionals to utilize aspects of each cluster perspective geared to the realities of their specific area.
\end{abstract}

Keywords : Technology entrepreneurship, Cluster theory, Economic development, Creative enterprise, Job multiples, Innovation management, Technology translation

\section{INTRODUCTION}

Technology-based economic development (TBED) (Bendis 2004) is recognized as an exceptional path for regional job and wealth creation. Many regions have demonstrated the ability to translate technology to its commercial promise (Enright 2003; Kohler and Som 2013). Most other regions seek to emulate these areas which include Silicon

*Correspondence to : Dr. Steven T. Walsh

The Morse Group Global Advisors, LA

Adjunct Faculty of the Alliant International University School of Management, San Diego

E-mail : swalsh91@comcast.net

World Technopolis Review

Copyright $\odot$ World Technopolis Association

CC This is an open-access article distributed under the terms of the Creative Commons Attribution Non-Commercial License(http://creativecommons.org/icenses/by-nc/3.0) which permits unrestricted noncommercial use, distribution, and reproduction in any medium, provided the original work is properly cited
Valley, Research Triangle, Boston and others (Allarakhia et al. 2012; Wonglimpiyarat 2006) by embracing their best practice. Today both newer and established regions are making commitments to commercializing emergent and sustaining technologies (van der Valk 2009) through the development of excellent science and technology in a process which often emphasizes the role science and technology parks (Anson et al. 2008; Kautt et al. 2007). Yet even these regions, despite utilizing successful regions best practices, have had mixed results translating their excellent science and technology to regional economic development (Cooke 2001; Amin 1999).

Here we seek to add to the knowledge base of regions seeking Schumpeterian rent by embracing emergent technology translation (Guo and Guo 2011). We do this through a discussion of economic-development-based cluster theories (Muro et al. 2010; 2011). We provide a structure for 
regional policy makers (Davidsson et al. 2002) and science and technology professionals to utilize the operationalizable concepts found in the variety of diverse economic cluster theories (Sölvell 2003).

Indeed operationalizing any of these economic cluster theories individually has proved difficult. Yet most professionals familiar with these "cluster theories" often find value in many of the underlying concepts and seek to include elements of many of them for regional development. If implementing any one of these theories is difficult then the pursuit of a practical policy that includes the multiple theoretical cluster perspectives for a specific region has proved frustrating. Here we provide a practical structure for the application of the various cluster theories that might help in the translation of science and technology for a specific regional economic development policy or plan (Benneworth et al. 2003; Cowan 2013).

We initiate a literature review with a discussion of economic development and the role of the Schumpeterian cycle in effective regional development (Schumpeter 1942; Kondratief 1937). We show the progression of economic development thought from Neo-Marshalian (Marshall 1890) concepts which focused on the attraction of large firms and manufacturing jobs to the more knowledge-based thought of Kirchhoff and others (Kirchhoff et al. 2013). These researchers showed that differential and sustainable economic development was most often based on the creation of entrepreneurial (Kirchhoff 1994) and small firms (Birch 1987) which utilized emerging and often disruptive technologies (Kirchhoff et al. 2000) technology. We further discuss in this segment of the paper the varied value that the attraction of large manufacturing firms has produced for sustainable regional successes.

We next investigate the strength and weaknesses of the five most popular cluster approaches. They include: The political model (Kirchhoff et al. 2013), the Birch-Kirchhoff model (Birch 1987; Phillips and Kirchhoff 1987), the Porter Model (Porter 1985; 1998) the triple Helix model (Etzkowitz and Leydesdorff 1997) and the creative class model (Florida 2002). Finally we seek to enable cluster theory users with economic and financial modules and metrics.

We provide a discussion of each wave of thought of economic cluster theory from the exceptional value from Keynesian job multipliers (Keynes 1937) to the attraction of key personnel which Florida (2002) calls creative class. We next move toward a progression of policy theory centered on clusters perspectives (Millis et al. 2008) that provide differing views of how best to achieve regional economic development. These theories provide policy direction for the problems that have vexed policy makers (Jiang and Fallah 2011), directors of research facilities (Romig et al. 2007), science and technology park directors (Eijkel et al. 2006), focused research centers (Tierney et al. 2013), economic development directors and those interested in regional economic development (Tierney et al. 2012). They provide disparate thought and each has generated fervent followers who embrace one or the other with almost religious conviction.

Further we suggest aligning the specific realities of a particular economic region to the elements of each cluster theory in order to provide a rational basis for each location to develop a specific economic policy. We provide a model designed to empower regional technology-based economic development professionals to embrace policy that will assist in the attraction, retention and creation of firms. Specifically we seek to add to the process of generating the policies and environment that enable targeted firms that can benefit from the policy and environment in the region and, in turn, benefit the population.

\section{LITERATURE}

Many have defined or tried to define economic development. Certainly we emphasize the efforts of Schumpeter (1942), Kirchhoff et al. (2013), Marshall (1890) and others here. But perhaps a more utilitarian definition will serve this effort even better. The World Bank defines "Economic Development" as a "Qualitative change and restructuring in a country's economy in connection with technological and social progress" (World Bank 2012). Today, economic development professionals are confined by the political process; especially, term length of regional political representation. Here we review the seminal thought in the literature that is used as a basis for implementation by regional economic developers who do not hesitate to embrace emergent technologies for economic renewal.

Economic development is centered on the idea of job and wealth creation for a city, community, region, county, state, country, continent or world. It usually implies a proactive activity focused on improving the general lot for the people in a given region and therefore addresses improving the average pay in a job, opportunity for youth and young pro- 
fessionals, the development of a "thick" employment profiles in selected business sectors, the quality of life in a region and providing for a more equitable distribution of wealth on a meritocracy basis (Kirchhoff 1994). The creation of wealth as well as jobs is critically important to the governance of any region since the creation of wealth is the only way to incentivize business to provide the jobs and create a more sustainable tax base (Kirchhoff 1994). There are many political realities that are often the drivers for a given economic development process. We provide a brief discussion of popular approaches to economic development below.

Adam Smith perhaps the progenitor of economic development theory (Smith 1776) is reported to have said, "Little else is requisite to carry a state to the highest degree of opulence from the lowest barbarism but peace, easy taxes, and a tolerable administration of justice: all the rest being brought about by the natural course of things (1755)" (as reported in Stewart 1793). These three items, viz., fiscal capacity, juridical capacity and the capacity for peaceful civil society, have been considered pillars of prosperity for an economy. In a macro sense, these three represent the triple helix at national level for political economic development. How these three have evolved together allows one to explain development clusters within an economy. Today economic development policy is dominated by cluster theory (Cortright 2006). Today's policy makers have a much larger base of knowledge than their industrial revolution forbears. Information abounds about the problems with emulating others rather than trying to leverage regional differentiating competencies. Many of these theories suggest that one can "cash in" by leveraging the past activities, but this is not the manner that would be most beneficial for emergent, often disruptive, technologies (Linton and Walsh 2004).

The five most popular cluster development approaches to economic development have many of the same ingredients. These ingredients include but are not limited to: regional competitive advantage, political drivers, educational activities, industrial synergies, government, and academia, entrepreneurial activities, large firms and small to medium enterprises (SMEs). Further many economic development policies focus on either initiating or sustaining a base for economic development. We provide a brief discussion of five cluster perspectives and in the conclusion suggest that none of these theories is the answer in and of itself. We instead provide one pathway whereby they might be utilized in a unified plan. In the segments below, we present their strengths and weaknesses and which approaches are popular with local groups. We provide a brief statement discussing each and then provide traditional pros and cons of each approach when recommending an economic development program based on emerging technology.

We, however, recognize that these approaches are essentially incomplete. Two additional actors are necessary to integrate and administer entrepreneurially what each approach is suggesting about the development of cluster for local economic development, whether city-wide or regionwide in a developed economy or in a transition economy. It will come as no surprise to learn that these two important actors collectively are (1) institutions for collaboration (IFCs) (Porter 1998) and (2) institutions for finance (IFFs). Examples of IFCs include chambers of commerce, industry associations, professional associations, local trade unions, technology-transfer centers, quality and management centers, and others which facilitate cooperation and complementarities among cluster-firms. IFFs help finance the infrastructure, facilities, plant and equipment and the like for a cluster and the firms within the cluster. Examples of IFFs include groups of angel investors, venture capital shops, private equity operators, community banks, lease finance firms, equipment finance firms, factor firms, initiatives sponsored by Small Business Administration, national labs' small business assistance (NBSA) programs, peer-to-peer lending programs such as Lending Club (which has broken the one-billion mark with Google's investment of $\$ 125$ million (Entrepreneur 2012).

We should like to think that a complete cluster approach to economic development would be to supplement Adam Smith's three pillars, viz., fiscal capacity, juridical capacity and the capacity for peaceful civil society, with two essential pillars identified above, viz., IFCs and IFFs. This prompts us to suggest a modification to the popular phrase, "five pillars"; we should like to call it the "quintuple helix approach". The designation makes immense sense because without the additional two categories of institutions and individuals none of the below-mentioned approaches would accrue positive results with speed and efficiency.

\section{ECONOMIC CLUSTER PERSPECTIVES}

The five most popular economic cluster perspectives include: the political perspective, the Porter or market per- 
spective, the Birch and Kirchhoff entrepreneurial perspective, the triple helix perspective, and the creative class perspective. The commonality across all approaches to using clusters as a means to economic development is the leveraging aspects of location proximity. This recognition of the advantages of proximity is interesting in itself given advances incommunication technology and trends toward globalization.

\subsection{The Political Perspective}

The political model is based on a government's necessary response to a social need or perceived need. It requires legislative action for the most part and works exceptionally well when the programs are beneficial for the people they serve and the legislators are recognized for their part in the activity. As succinct as possible the benefits and problems are captured in the old adage: "One job equals one vote" (unattributed). This is time sensitive and job sensitive Perspective. It initially caused economic developers to seek large infrastructure projects and the attraction of large firms with large production personnel needs (Marcy 1975)

On the positive side this model has given rise to numerous activities centered on the concept of job multiples which is a key factor in economic development based on emergent technologies. Job multiples are the notion that for every new job created a number of secondary jobs are created in both the local- and overall-economy. This has given rise to the notion that not all jobs are created equal in terms of multipliers. For example, it has been recognized that manufacturing jobs have much higher job multiples than retail jobs both in the region and in the larger community. Likewise, most economic development officials with whom we have discussed the matters believe that emergent technologies have a higher multiplier effect than firms developed around traditional technologies.

On the negative side, the economic horizons for programs developed in this manner are significantly correlated with the length of time a legislator is in office for any given election cycle (i.e., two to six years). This myopic behavior encourages policies for immediate economic development at the cost of the emphasis on sustainable economic development. A typical primer for this paradigm of economic development discusses numerous activities related to firm creation, firm expansion (and/or stability) and firm attraction, yet over-emphasizes firm attraction due to the immediacy of the result.

Even though the political model for economic development is a great step forward toward explaining the "short-termism", this short-term view can result in unintended conse- quences. For instance, it can foster the convergence of competitive policy across jurisdictions leading to little overall economic development, thereby making the convergence a zerosum game (Adkisson 2013). Adkisson provides an example of this by studying film-production tax credits across states. While the production often moved outside the market-leading states of California and New York, the movement tended to reduce the enacting state's tax revenues with little to show in terms of permanent clusters of activity.

This form of targeted tax incentive is often the policy of choice for implementation of the political model. It, however, loses sight of the fact that the organic growth of clusters or the movement of firms to a given area is often a function of other factors. Site selection consultants often look to attributes such as existing workforce, education quality, infrastructure costs and access to transportation rather than mere shorter-term fiscal incentives.

Another unintended consequence of the political approach, especially in advanced economies, is that governments or their development agencies often crowd out private-sector leadership in cluster development. Because public sector bureaucrats are more attentive to their political masters who might remain so only until the next election, myopia of legislative and regulatory structures becomes a hindrance. Research undertaken by Ketels, Lindqvist and Sölvell (2005) on behalf of the US AID and the Global Cluster Initiative Survey points out that this problem is less serious in developing and transition economies where governments generally play a smaller role. The important roles of IFCs and IFFs are diminished in this strategy thereby hampering the development of these institutions themselves. When intermediaries lose their potential, the sectors which depend on their skills and efficiency suffer.

Lastly the short-term nature of the political model incentivizes the embrace of large firm production facilities which tends to create an immediate large demand for production workers. This may maximize immediate job creation but it is often at the cost of a long-term sustainable economy. Some of the more telling examples are given below.

Intel undertook expansion efforts in the mid-1980s. Intel was courted for its two facilities by a number of communities seeking to improve their economic conditions. One of the facilities Intel wished to build was a major semiconductor manufacturing plant whereas the other was a smaller manufacturing facility with a major research and development facility as well as marketing personnel. In this case two areas were 
ultimately successful in securing these facilities. Most regional economic development professionals saw the attraction of the manufacturing facility with a larger employment base as the plumb between the two facilities. Now over twenty years later both the larger manufacturing facility and the smaller Intel facility are still employing thousands of knowledge workers.

Yet the larger facility did not match the spin-out multiplier (Chemmanur 2004) of its smaller cousin. The smaller facility with combination of production, research and development and marketing has spun out well over 100 firms whose total employment exceeds that of the other region's now-sustaining manufacturing facility. Contrastingly, the larger manufacturing facility has spun out fewer than ten firms with a much smaller relative contribution to regional employment (Cowan and Walsh 2011). This suggests that the type of large-firm facility attracted is important.

Both of the above locations are successes in that the attracted facilities continue to prosper. But what happens when an attracted production firm facility fails? When the attracted firm brings only a manufacturing presence, it fails to grow the workforce because of a lack of spin-out development (Cowan and Walsh 2011). Regions often "crater" in terms of job retention and the firms actually harm the regions they were wooed to. This has occurred in numerous diverse regions around the world. Automotive manufacturers seeking to expand into new regions have placed regional manufacturing in the countries where they were expanding. For many Japanese auto firms seeking to expand in the U.S. the locating of a plant has been successful, yet they have hardly grown the local pool of employers. The attraction and subsequent demise of Japanese auto manufacturing facilities have cratered a region's employment in Australia. Similar regional employment problems occurred in the United States when a European auto manufacturer closed its doors a few decades after starting the operations.

\subsection{The Porter or "Market" based Perspective}

The Porter model emphasizes cluster and cluster development based on four factors and is market-centric (Porter 1998). Porter's four factors are: demanding customers; suppliers; factor inputs; and systems integrators. He develops the ideas in one of his earlier works (Porter 1985). He states that regional clusters of excellence occur when factor inputs (from universities, national laboratories and the like in a given application arena) are combined with (1) demanding regional customers, (2) an intensive supplier network enables, and (3) new firms that act as systems integrators.
These clusters are "enabled" to provide value on a worldwide basis. This model finds support from the Milken Institute, venture capitalist firms and angel investors.

On the positive side, the market-based model is easy to understand and consistent with the political model in many respects. It supports the attraction of both large and small firms and is focused on the development of new firms. It forces the attention of clusters upon a few. Numerous groups including the Milken Institute base much of their cluster efforts around this concept.

On the negative side, the market-based model requires a focus on a market. The model is static and does not allow for a disruptive technology to supplant an existing product market paradigm. This is problematic for areas that are small or may not have a naturally occurring adequate demand if an insufficient number of customers exist. Such conditions make it very difficult to develop a cluster group centered in any area without a local large demand.

This model works best for existing markets and an operating paradigm emphasizing improvement to an existing technological infrastructure. It does not offer insights into ways to promote clusters centered on emergent technology where no local demand exists. This model reminds one of a vertically integrated manufacturer. The approach results in a company town but not necessarily in a vibrant cluster. The roles of both IFCs and IFFs are diminished in this case. They are able to and may continue to service the local scene but they are unable to be catalysts for new firm so as to serve them continually.

\subsection{The Birch and Kirchhoff or "Entrepreneurial" Perspective}

The entrepreneurial or Birch and Kirchhoff model is based on the ideas of Schumpeter (Schumpeter 1942) concerning R\&D and entrepreneurship and finds passionate advocates at the Small Business Administration (Birch 1979 and 1987; Spencer et al. 2008). These academics point to a large body of empirical evidence that the majority of net new jobs is generated not by existing firms but new ones. They focus on the "bottom-up" element in cluster development stressing the presence of research universities and laboratories that generate knowledge and professionals in areas such as engineering, management and medicine. They focus on good infrastructure in roads and communications and travel and other related things.

On the positive side, this approach recognizes the vital 
important role of new firm development for sustainable economic growth. Further it stresses the precursors to economic growth and features the generation of new firms in economic development. It allows for the development of a cluster without the necessity for governmental policy or for a regional demand or for a large market. It is consistent with cluster development on the basis of emergent disruptive technology and a market development or expeditionary marketing (Prahalad and Hamel 1990). It is a competence based perspective (Prahalad and Hamel 1991) that leverages exceptional university's or industry's research activities and resources like students, professors and intellectual property. The approach is extraordinarily wide in scope (more holistic) thereby welcoming of the active participation of IFCs and IFFs for development. Under these conditions, IFCs and IFFs may be viewed as good midwives who assist in the birth of innovative firms.

A key factor in the Entrepreneurial Model is the culture and opportunity to promote the creation or spin-off of new firms to foster innovation (Cooper 1971). For instance, this is a primary feature of universities and anchor firms (see the Intel example earlier in the paper). Academic institutions or firms either recognized or allowed the development of the related innovations in nearby firms. Likewise, research laboratories like Bell Laboratories (Linton et al. 2002), Xerox PARC (Chesbourough 2002a; 2002b) and Sandia National Laboratories (Kassicieh et al. 2002) can and have encouraged similar outcomes through entrepreneurial support policies such as leave of absence, sabbaticals, consulting and operational support and the like.

On the negative side, however, it is not consistent with the immediacy required by the political approach. It stresses, "Do your homework (as a region)," rather than the immediate outcomes of attracting a production facility from an established firm. The theory represents a micro-level concept of developing precursors to economic development thereby providing a solid foundation for the same. It does not link a local market of demanding customers and such for job creation and wealth improvement. Because of its focus on building blocks rather than structures themselves, it is not as easy to understand as Porter's argument.

\subsection{The Triple Helix Perspective}

The Triple Helix concept (Etzkowitz and Leydesdorff 1997) takes into account the shifting of most industrialized economies from an agricultural to a manufacturing to a ser- vice-based to a knowledge-based economy. By its very nature, it includes the market perspective of the Porter model, captures some of the competency arguments of the Kirchhoff and Birch Entrepreneurial Model and recognizes some of the political/governmental/regulatory realities found in the political model. The triple helix model propounds commercial interaction among (1) Academia, (2) Industry and (3) Government in order to generate the most social good out of knowledge generation. This three-legged stool is the basis of support of cluster and economic development.

On the positive side, the triple helix perspective is focused on gaining maximum social benefit from knowledge generation. It is compatible with the patience required to develop emerging-technology-based products. Yet the success of emerging technologies requires action from lead users and this model does not specifically or explicitly include these supporters from within the triple helix of academia, industry and government (Etzkowitz and Leydesdorff 1997). The existence of intermediaries, IFCs and IFFs, however, would need to be considered implicit. If industries and governments exist to provide a base for current economic conditions, it stands to reason that IFCs and IFFs exist to service them. Whether IFCs and IFFs can leverage their expertise to accelerate further economic development remains unknown.

On the negative side, the triple helix perspective is a limited model. It is surely useful for emerging technology development. The concept has been used with resounding success in the generation of R\&D efforts focused on technologytranslation. The combination of academia, industry and government has generated interest, action and resources for development and user facilities such as Mesa+ in the Netherlands, Center for Integrated Nanotechnologies in Albuquerque and a number of other technopolises such as Kennispark in the Netherlands (Eijkel et al. 2006). Similar to the entrepreneurial perspective, it focuses on precursors to economic development and is not necessarily a vehicle for instant development that the political model expounds.

Most of the economic-development professionals with whom we have conferred believe that this approach, like all of the cluster theories, is a piece of the puzzle of the economic development model rather than the whole puzzle of the economic development model. Two of the three components of this model are academia and government none of which is exactly well-known for providing a pro-active and prompt response to changing business environment. These two groups often look backward trying reactively to explain what happened, assign blame and preserve existing jobs 
instead of welcoming new economic engines. This cluster development model despite its inclusion of academia, industry and government has proven to not be as all-encompassing as once thought. This model does not acknowledge the importance of IFCs and IFFs to the necessary extent, thereby needlessly slowing and sometimes preventing exponential growth of clusters.

\subsection{The Creative Class Perspective}

The last of the cluster economic development perspectives under review is Florida's concept of the creative class (Florida 2002; 2007; 2008). This is the newest thinking on economic-development front and models cluster development through a sociological and a network point of view. Perhaps because of its novelty, it has become immensely popular.

Florida focuses on specific precursors to cluster development. He discusses the importance of the creative class of individuals or groups of individuals who (which) possess the three Ts (talent, technology and tolerance). His thesis centers on job and wealth creation through new firm development, entrepreneurship and on cultural efforts necessary for new commercial ideas to be germinated, tolerated, accepted, implemented and fostered.

On the positive side, the concept of the rise of the creative class is a bottom-up model that does not require an active market presence of various factors à la Porter. It fits well with the entrepreneurial viewpoint of emergent technology-based economic development. It speaks to both sustaining- and emerging-industry-based models for an improved economy. The perspective focuses on driving creative people toward appropriate environments that will support innovation and creation.

In order to assist regions to become havens for the creative class this perspective provides them a socially-motivated checklist for a community's ability to nurture a nascent economy. In this regard, this model implicitly appropriates motivations lurking behind the political model: The community through its political will will attract a creative class. Indeed Florida ranks numerous cities on their ability to incubate and attract the creative class. This perspective provides technopolis professionals' actionable steps to move toward a better economic progress, exemplified by frequent and regular incubation of innovation.

On the negative side, this is the newest perspective on economic development and has not yet stood the test of time like the other models. The dominant problem with this perspective is the proposition on which it has built its edifice that one group of human beings is simply better than the rest of the human race in developing commercial innovations. Additionally these innovators or creative class professionals are in many ways born that way. It has little room for training individuals to be innovators. Historically and politically this is a difficult position to defend. Even though all individuals want to be elite this perspective would play well only in those communities which already view themselves as elite. This perspective is unlikely to be received well among masses, or for example, the Unites States which subscribes to a traditional American ethos that all individuals are enabled to be exceptional. This, strangely enough, diminishes the roles of politics and politicians.

Another criticism of this perspective is found in the suggestion of the "Flight of the Creative class." Florida suggests that these "Uber"-creators are not necessarily rooted in any single community. Thus the creative class will not hesitate to move when conditions change; these uber-creative individuals and entrepreneurs among them will simply move to a more favorable environment. This suggests that the longterm growth which most economic-development professionals seek will not be attained without catering to an elite group. Note that this catering would require government to put in place policies that will favor one influential, but not necessarily large, group, consequently sowing the seeds of discontent among the less-favored.

This approach is general enough to accommodate an integral development of IFCs and IFFs, even though the focus is elsewhere. Indeed IFCs would be of particular importance to supporting the creative class. Yet this perspective as with other models does not address fully the need for institutional infrastructure.

\subsection{A visual comparison of these 5 cluster perspectives}

Each of these cluster perspectives provides value to a regional economic development activity. Here, in <Table 1> we provide a visual comparison of all the 5 perspectives focus on their developmental goal; founding theoretical perspectives, perceived strengths, researcher foundations, and perceived weaknesses. As depicted and discussed above all cluster perspectives have great strength and weaknesses and none adequately address the financial perspective. The managerial implications involved in the choice and ultimate use of elements found in the five perspectives have tradeoffs. 
The tradeoffs are different for each perspective. The emphasis of the Market or Porter perspective is warranted in the cases of large local markets but has limited applicability in areas which do not have market leaders. The political perspective for example has historically favored the attraction of large production facilities at the expense of fostering indigenous small and entrepreneurial activities as stated in $<$ Table $1>$ below.
The complexity and necessity of aligning of differing interest groups has limited the applicability of the "Triple Helix" perspective. The embrace of the "elite' by many of the "creative class" perspective is equally opposed by others who are repulsed by what they consider Fascist like undertones of the perspective. We provide a brief discussion of the strengths and weakness of all the perspectives in $<$ Table $1>$ below.

Table 1. A comparison of the five cluster perspectives.

\begin{tabular}{|c|c|c|c|c|c|}
\hline Perspective & Goal & Perspective & Strengths & Authors & Perceived weaknesses \\
\hline $\begin{array}{l}\text { Political } \\
\text { Perspective }\end{array}$ & $\begin{array}{l}\text { Time sensitive job } \\
\text { development }\end{array}$ & $\begin{array}{l}\text { Public } \\
\text { Administration } \\
\text { time scope }\end{array}$ & $\begin{array}{l}\text { 1) A region Where } \\
\text { Political terms are } \\
\text { longer } \\
\text { 2) Attracting firm and } \\
\text { large govt. products }\end{array}$ & $\begin{array}{l}\text { Darby, M. } \\
\text { (1975) }\end{array}$ & $\begin{array}{l}\text { 1) Temporal effect } \\
\text { 2) Recirculation of Funds } \\
\text { 3) Sustainability } \\
\text { 4) Susceptible to dominate firm "Cratering" } \\
\text { a economy } \\
\text { 5) Does not emphasize role of small firms }\end{array}$ \\
\hline $\begin{array}{l}\text { Porter or } \\
\text { Market } \\
\text { Based } \\
\text { perspective }\end{array}$ & $\begin{array}{l}\text { Sustainable } \\
\text { regional market } \\
\text { based ecosystem }\end{array}$ & $\begin{array}{l}\text { Market } \\
\text { perspective }\end{array}$ & $\begin{array}{l}\text { 1) A region with large } \\
\text { markets } \\
\text { 2) Supply Chain } \\
\text { Management }\end{array}$ & $\begin{array}{l}\text { Porter, M. E. } \\
\text { (1998) }\end{array}$ & $\begin{array}{l}\text { 1) Does not focus on bringing funds into } \\
\text { region } \\
\text { 2) Does not provide great value for regions } \\
\text { without large markets } \\
\text { 3) Role of small firms }\end{array}$ \\
\hline $\begin{array}{l}\text { Birch and } \\
\text { Kirchhoff or } \\
\text { Entreprenuer } \\
\text { Perspective }\end{array}$ & $\begin{array}{l}\text { A growing econo- } \\
\text { my based on } \\
\text { knowledge work- } \\
\text { ers and knowl- } \\
\text { edge providers }\end{array}$ & $\begin{array}{l}\text { Competence } \\
\text { and Resource } \\
\text { based firm } \\
\text { perspective }\end{array}$ & $\begin{array}{l}\text { 1) A region with excep- } \\
\text { tional universities } \\
\text { 2) A region with } R \& D \\
\text { and other knowledge } \\
\text { providers }\end{array}$ & $\begin{array}{l}\text { Birch, D. L. } \\
\text { (1979) } \\
\text { Kirchhoff, } \\
\text { B. A.(1994) }\end{array}$ & $\begin{array}{l}\text { 1) Does not focus on large firms } \\
\text { 2) Requires a region to emphasize on small } \\
\text { and entrepreneurial firms } \\
\text { 3) Requires a long term view of economic } \\
\text { development with patient money sources }\end{array}$ \\
\hline $\begin{array}{l}\text { Triple Helix } \\
\text { Perspective }\end{array}$ & $\begin{array}{l}\text { A sustainable } \\
\text { interaction } \\
\text { between } \\
\text { Industry, govt } \\
\text { and Academia }\end{array}$ & $\begin{array}{l}\text { Resource } \\
\text { based per- } \\
\text { spective and } \\
\text { competence }\end{array}$ & $\begin{array}{l}\text { 1) A region with } \\
\text { existing vibrant } \\
\text { industries, Academic } \\
\text { institutions and } \\
\text { government will }\end{array}$ & $\begin{array}{l}\text { Etzkowitz } \\
\text { and } \\
\text { Leydesdorff } \\
\text { (1997) }\end{array}$ & $\begin{array}{l}\text { 1) A highly complex model } \\
\text { 2) Necessity to align large and small firms, } \\
\text { local regional and often federal govern- } \\
\text { ments, and differing laboratories and uni- } \\
\text { versities around a single economic devel- } \\
\text { opment strategy }\end{array}$ \\
\hline $\begin{array}{l}\text { Creative } \\
\text { Class } \\
\text { Perspective }\end{array}$ & $\begin{array}{l}\text { An attraction of a } \\
\text { group of people } \\
\text { designated as the } \\
\text { creative class }\end{array}$ & $\begin{array}{l}\text { Tolerance, } \\
\text { Talent and? } \\
\text { Trait theory }\end{array}$ & $\begin{array}{l}\text { 1) A region which is } \\
\text { desirable to live in. } \\
\text { 2) A region which has } \\
\text { required innovator } \\
\text { elements for } \\
\text { business success }\end{array}$ & $\begin{array}{l}\text { Florida } \\
(2002,2007 \\
\& 2008)\end{array}$ & $\begin{array}{l}\text { 1) Suggests there is a class of people that } \\
\text { are desirable to attract and others are } \\
\text { not useful in process } \\
\text { 2) Sustainability; as discussed by the author } \\
\text { the creative class will leave any region for } \\
\text { one they perceive to be better } \\
\text { 3) Trait theory }\end{array}$ \\
\hline
\end{tabular}

\section{AN INTEGRATED CLUSTER MODEL FOR ECONOMIC DEVELOPMENT}

The professionals in the regions examined were not simply using one of these models for the advancement of their regions economic development. Rather they adopted approaches which combined aspects of several perspectives. These professionals recognized the value in all of the differ- ing cluster perspectives but stated that the realities of any region would dictate the value that a particular region could extract from a particular cluster perspective.

The economic region's environmental reality is important in this process. No one of these economic cluster perspectives is a "One size (perspective) fits all (regions)" and all perspectives provide seminal thought on these activities. For example, it would be naive to suggest that a market and an 
existing economic infrastructure are not important. But what does this perspective suggest for smaller more market isolated community with only a few or no intrinsic markets? Are these regions simply "Out of Luck"? Is there another path, one that depends on the inherent resources in a community, available to the community?

Every economic region or technopolis seeking economic development starts out with a will (we prefer to not call it "political will" and so we label it "communal will") to change their economic status and initiate a preferred path to achieve that goal. This communal will and preferred pathway have to be modified in light of the environmental realities of that region. The aforementioned cluster perspectives can aid in forming the communal will as well as guide the development of a modified approach.

Here we provide a simple interactive economic development model that emphasizes the inclusion of a more financial attribute often glossed over which we have named the five pillars and are based on Adam smith three pillars (Smith 1776) (see <Fig. 1>). It further includes the use of cluster perspectives with aspects of each cluster tool used to operationalize and modify regional will and are seen in our as tools interacting on the regional will process from eachside in the center of our figure. We provide another important factor elevating it to a dynamics which assists the economic development group to choose aspects of any of the five cluster perspective and move forward.

We in $<$ Fig. $1>$ provide our linear model that is comprised of four elements. These elements are (1) the region's communal will for fostering economic development, (2) the region's economic environmental reality, (3) the five popular cluster perspectives and (4) the five pillars. Integrating these four elements provides a economic development process that is results in compelling comprehensive plan of regional policy actions and activities. We discuss the elements of our integrated economic development process below.

The operationalization of cluster perspectives into an economic development plan focuses on taking the elements of a single cluster perspective and operationalizing it. We initiate our comprehensive economic development plan by first trying to align perspectives of each cluster perspective to the realities and will of the region embracing economic change. The emphasis of the objective reality of the region and the normative regional will differentiates our process from others.

First, we recognize in our model that there must a communal will for change in a particular region. We have named this element the normative regional communal will. It is the initiator of economic development action. Here a region needs to initiate its effort by considering the degree to which it wishes to attract, generate or empower local firms in their process of job and wealth creation. Further this region will generation process recognizes that the will to change is a continuum and significant regional will is needed to change the economic status quo in terms of jobs and prosperity opportunities.

We name the second element is our model the regional economic reality. This is what the normative regional communal will encounter and in association with the regional will determines the aspects of each cluster perspective that a region is likely to include into a successful plan. The interactions within this decision space are the interaction of the elements of numerous cluster perspectives, e.g., relative market position of the region, political actors, entrepreneurial with the innovative spirit of the community, and the regional realities.

Regional realities include; the existence or non-existence of large regional markets, The presence of or proximity to a major research university, the quantity and quality of IFCs, IFFs, and other five pillar elements. The regional ecosystem is also characterized ability of the region to attract and maintain a creative class. Regional dynamics between Industry, Academia and government plays a dynamic role and finally the time constraints of political professionals play a profound role.

All of these are stressed by the needs of the nature of the technopolis. For example the regional ecosystem plays a profound role region's ability and willingness to accept emerging-technology-based technological competence and uniqueness thereof. In other words, the idea is to nurture a unique "endowment" of technological prowess which lends the region a kind of monopolistic power for human resources. Many-a-time this can be quantified by a region's investment in technopolis infrastructure such as emergent-technology development centers through science and technology parks, specialized training institutions and their capabilities, institutions of higher learning and similar means of developing human capital. The regional environment is enhanced by the degree to which IFCs and IFFs are already established and actively engaged in fulfilling their raison d'être. Lastly the critical level of existing appropriate knowledge workers is determined by regional universities or research facilities.

The third element of the process is the many ways in which components of each cluster perspective can be used to develop an economic-development engine unique for a 
particular region's communal will and its circumstances. The crucial components of the five cluster perspectives are salient here. If you don't have great sources of knowledge the triple Helix approach and the entrepreneurial approach are not as important. If your region does not have large markets the Porter approach loses much of its vigor. If Academia, Industry and Government actors are suspicious of one another then elements or the Helix may be difficult to apply. Finally if you do not have a destination that is attractive to a creative class then generating or perusing this group may not lead to timely results. Yet each of these perspectives has elements important for a region to utilize in their search for economic change. These realties lead to an integrated approach that applies most aptly to that region.

The fourth element of the process is the existence of the five pillars. The region would make rapid progress if a goodly dose existed of the Adam-Smith-three, viz., fiscal capacity, juridical capacity, the capacity for peaceful civil society, supplemented by strong IFCs and IFFs. These will help us assess the competence pool on which clusters can be built resulting in sustained economic development.

Thus to review: The five pillars provide the air (or ether) in which the five cluster perspectives together can provide the necessary boost to economic development. In particular we have included Kirchhoff and Birch's entrepreneurial and competence perspective (Kirchhoff 1994; Prahalad and Hamel 1990), Porter's market perspective (Porter 1985), Florida's emphasis on innovator attraction and retention (Florida 2002), the political perspective, and Etzkowitz's triple helix network perspective (Etzkowitz and Leydesdorff 1997).

The critical interaction among these four elements results in a regional policy of actions and activities to spur economic development. We recommend that the regional realities- economic and otherwise- modify normative communal will of a region as well as the application of elements of each cluster perspective. The inclusion of the above boundary conditions when embracing differing cluster perspectives provide a richer context for economic-development action as portrayed in $<$ Fig. $1>$.

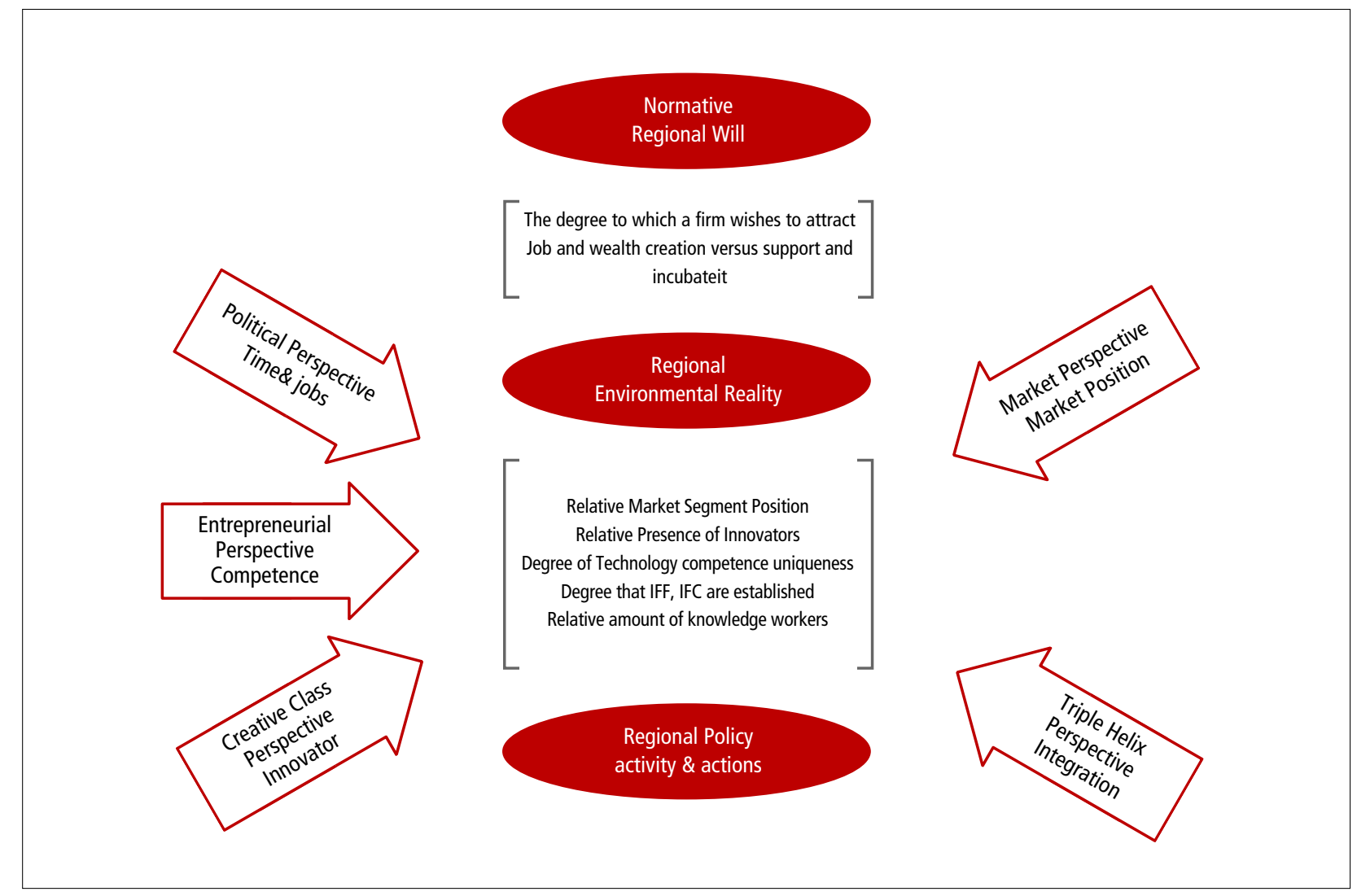

Fig. 1. An Integrated Model for the Utility of Cluster Perspective for a Specific Region's Technology Based Economic Development 


\section{DISCUSSION}

We have provided a discussion of the merits and problems with each cluster perspective. We have shown how each might add value to a region searching for competitive advantage for regional economic development. We suggest an integrated model leveraging the strengths of the differing cluster perspectives modified by the realities of a specific regional environment. We provide a model for its implementation. Finally we provide eleven (11) general lessons from our approach for discussion and future research. They are:

1. The three pillars suggested by Adam Smith are a simple pre-requisite for technology based cluster development.

2. The public-private partnership must be cultivated carefully in regional economic development so that none of the important parties is crowded out.

3. A presence of all the five pillars in close proximity in a region is useful for communication and joint development.

4. The presence and active participation of IFCs and IFFs are crucial for the success of cluster initiatives.

5. The political, industrial and academic myopias need to be kept in firm check.

6. Cluster initiatives are long-term projects and therefore they rarely produce glorious short-term results. Regional economic development activities need patience to succeed.

7. Cluster initiatives do not thrive with monopolistic access to projects and funding; they are more likely to excel if exposed to competition.

8. Cluster initiatives based on emerging and often disruptive technologies are not substitute for commercial development activities that focus on encouraging consumer acceptance of new-to-the-world products and redefining existing customer expectations; at best they are supple mentary.

9. Cluster initiatives based on sustaining technologies are no substitute for market-inspired development; at bestthey are complementary.

10. Organically-grown clusters are likely to be more robustthan mandated clusters.

11. A comparative advantage is not a pre-requisite for cluster development; however a cluster- based economic development process could provide a comparative advantage.

\section{REFERENCES}

Adkisson, R.V. (2013) "Policy Convergence, State Film Production Incentives, and Employment: A Brief Case Study," Journal of Economic Issues 47(2): 445-54.

Allarakhia, M., and Walsh, S.T. (2012) "Analyzing and Organizing Nanotechnology Development: Application of the Institutional Analysis Development Framework to Nanotechnology Consortia," Technovation 32(3/4): 216-26.

Amin, A. (1999) "An Institutionalist Perspective on Regional Economic Development," International Journal of Urban and Regional Research 23(2): 365-78.

Anson, S., Kautt, M., Walsh, S.T., and Bittner, K. (2008) "Academic Infrastructure and Competence Centres for a potentially evolving Nano-manufacturing industry," International Journal of Technology Transfer and Commercialization 7(4): 436-545.

Bendis, R.A. (2004) "Technology Based Economic Development," in edited by Fernando Duarte Carbalho, Defence Related SME's: Analysis and Description of Current Conditions, NATO Science Series; Series V: Science and Technology Policy Vol. 43 (Amsterdam, Netherlands: IOS Press), 1-89.

Benneworth, P., Danson, M., Raines, P., and Whittam, G. (2003) "Confusing clusters? Making sense of the clusters approach in theory and practice," European Planning Studies 11(5): 511-20.

Birch, D. L. (1979) The Job Generation Process, Unpublished Report Prepared by the Massachusetts Institute of Technology Program on Neighborhood and Regional Change for the Economic Development Administration (Washington, DC: U.S., Department of Commerce).

Birch, D. L. (1987) Job Creation in America: How Our Smallest Companies Put the Most People to Work (New York, NY: Free Press).

Chemmanur, T. J., and Yan, A. (2004) "A Theory of Corporate Spin-Offs," Journal of Financial Economics 72(2, May): 259-90.

Chesbrough, H., and Rosenbloom, R.(2002a) "The Role of the Business Model in Capturing Value from Innovation: Evidence from Xerox Corporation's Technology Spin-Off Companies." Industrial and Corporate Change 11(3, June): 529-55.

Chesbrough, H. (2002b) "Graceful Exits and Missed 
Opportunities: Xerox's Management of Its Technology Spin-Off Organizations," Business History Review 76(4): 803-37.

Cooke, P. (2001) "From Technopoles to Regional Innovation Systems: The Evolution of Localised Technology Development Policy," Canadian Journal of Regional, Science 24(1): 21-40.

Cooper, A. C. (1971) "Spin-offs and technical entrepreneurship," IEEE Transactions on Engineering Management EM-18(1): 2-6.

Cortright, J.(2006) Making sense of clusters: Regional competitiveness and economic development, Brookings Institution, Metropolitan Policy Program.

Cowan, K., and Walsh, S. (2011) "Spin Out Multipliers: Implications for a New Economic Development Metric," Proceedings of PICMET 2011, Technology Management in the Energy Smart World, Portland, Oregon (July 31 - Aug 4 2011), 1-4.

Darby, M.R. (1975) Three and one half million employees have been Mislaid, or an Explanation of Unemployment. 1934 - 1941, National Bureau of Economic research (NBER) working paper series 88 (Cambridge, MA: National Bureau of Economic Research).

Davidsson, P., Kirchhoff, B. A., Hatemi, J. A., and Gustavsson, H. (2002) "Empirical Analysis of Business Growth Factors Using Swedish Data," Journal of Small Business Management 40(4): 332-49.

Etzkowitz, H., and Leydesdorff, L. (1997) Universities in the Global Economy: A Triple Helix of UniversityIndustry-Government Relations (London: Cassell Academic), 19.

Eijkel, K., Knol, E., and Walsh, S. (2006) "Architectural innovations in perspective," In M. A. Doorn (eds.), Converging technologies: innovation patterns and impacts on society, STT Netherlands Study Centre for Technology Trends, 244-65.

Eha, B.P. (2012) "Google leads a \$125 million investment in lending club," in Entrepreneur, available at http://www. entrepreneur.com/article/226556 or http://dealbook. nytimes.com/2013/05/02/google-to-invest-in-lendingclub.

Enright, M. J. (2003) "Regional clusters: What we know and what we should know," in: Bröcker, Johannes, Dirk Dohse and Rüdiger Soltwedel, Eds., 2003, Innovation Clusters and Interregional Competition (Berlin: Springer-Verlag), 99-129.
Florida, R.L. (2002) The Rise of the Creative Class: And How It's Transforming Work, Leisure, Community and Everyday Life (New York, NY: Basic Books).

Florida, R.L. (2007) The Flight of the Creative Class: The New Global Competition for Talent (New York, NY: Harper Collins).

Florida, R.L. (2008) Who's Your City: How the Creative Economy is Making Where to Live the Most Important Decision of Your Life (New York, NY: Basic Books).

Guo, B., and Guo, J. J. (2011) "Patterns of technological learning within the knowledge systems of industrial clusters in emerging economies: Evidence from China," Technovation 31(2/3): 87-104.

Jiang He, M., and Fallah, H. (2011) "The typology oftechnology clusters and its evolution - Evidence from the hi-tech industriesThe typology of technology clusters and its evolution - Evidence from the hi-tech industries," Technological Forecasting and Social Change 78(6, July): 945-52.

Kassicieh, S. K., Kirchhoff, B. A., McWhorter, P. J., and Walsh, S. T. (2002) "The Role of Small Firms in the Transfer of Disruptive Technologies," Technovation 22(11): 667-74.

Kautt, M., Walsh, S., and Bittner, K. (2007) "Global distribution of micro-nano technology and fabrication centers: A portfolio analysis approach," Technology Forecasting and Social Change 74(9): 1697-717.

Ketels, C., Lindqvist, G., and Sölvell, O. (2006) Cluster initiatives in developing and transition economies (Stockholm: Center for Strategy and Competitiveness, Stockholm School of Economics). Available at: http://egateg.usaidallnet.gov/sites/default/files/Cluster\%2 OInitiatives\%20in\%20Developing\%20and\%20Transition\% 20Economies.pdf.

Keynes, J.M.(1937) "The General Theory of Employment," The Quarterly Journal of Economics 51(2): 209-23.

Kirchhoff, B. A.(1994) Entrepreneurship and Dynamic Capitalism: The Economics of Business Firm Formation and Growth, Praeger studies in American industry (Westport, CT: Praeger).

Kirchhoff, B. A., and Walsh S.T.(2000) "Entrepreneurship 's Role in Commercialization of Disruptive Technologies," Band 13, Unternehmer und Unternehmensperspektive fur Klien-und Mittelunternehmen (Berlin, Germany: Dunker and Humbolt), 323-32.

Kirchhoff, Linton, J.D., and Walsh, S.T. (2013) "Neo-Marshellian 
Equilibrium versus Schumpeterian Creative Destruction: Its impact on Business Research and Economic Policy," Journal of Small Business Management 51(2): 159-66. Kondratieff, N.D. and Stolper,W.F. (1935) "The long waves in economic life." Review of Economic and Statistics 17(6): 105-15.

Köhler, A., and Som, C. (2013) "Risk preventative innovation strategies for emerging technologies the cases of nanotextiles and smart textiles," Technovation, available at http://dx.doi.org/10.1016/j.technovation.2013.07.002 [in press]. accessed 30 july 2013.

Linton, J.D., and Walsh S.T.(2004) "Roadmapping: from sustaining to disruptive technologies," Technological Forecasting and Social Change 71(1-2): 1-3.

Linton, J., Walsh, S., and Moribito, J. (2002) "Analysis, Ranking, and Selection of R\&D Projects in a Portfolio," $R \& D$ Management 32(2): 139-48.

Marshall, A. (2012) Principles of Economics (A Digireads.com book, Digireads.com publication).

Mills, K. G., Reynolds, E.B., And Reamer, A. (2008) Clusters And Competitiveness: A New Federal Role For Stimulating Regional Economies, Blueprint For American Prosperity; Unleashing The Potential of A Metropolitan Nation, April 2008, (Brookings Institution: Metropolitan Policy Program At Brookings).

Muro, M., and Kenan, F.(2011) Job Creation On A Budget: How Regional Industry Clusters Can Add Jobs, Bolster Entrepreneurship, And Spark Innovation, Brookings-Rockefeller Project on State and Metropolitan Innovation, January 2011 (Brookings Institution: Metropolitan Policy Program at Brookings).

Muro, M., and Katz, B.(2010) The New 'Cluster Moment': How Regional Innovation Clusters Can Foster The Next Economy, September 2010 (Brookings Institution: Metropolitan Policy Program at Brookings).

Porter, M. E.(1985) Competitive Advantage (New York, NY: The Free Press).

Porter, M. E. (1998) "Clusters and the new economics of competition," Harvard Business Review 76(6, Nov-Dec): 77-90.

Phillips, B. D., and Kirchhoff, B. A. (1989) "Formation, Growth and Survival: Small Firm Dynamics in the U.S. Economy," Small Business Economics 1: 65-74.

Prahalad, C., and Hamel, G. (1990) "The Core Competence of the Corporation," Harvard Business Review 69(4, May/June): 79-91.
Prahalad, C., and Hamel, G. (1991) "Corporate Imagination and Expeditionary Marketing," Harvard Business Review 69(4): 81-92.

Romig, A., Baker, A., Johannes J., Zipperian, T., Eijkel, K., Kirchhoff, B., Mani, H.S., Rao, C.N.R., and Walsh, S.(2007) "An introduction to nanotechnology policy: Opportunities and constraints for emerging and established economies," Technological Forecasting and Social Change 74(9): 1634-42.

Schumpeter, J. A. (2013) Capitalism, socialism and democracy (New York, NY: Routledge).

Smith, A.(1776) An Inquiry into the Nature and Causes of the Wealth of Nation (London: Methuen and Co.).

Sölvell, Ö., Lindqvist, G., and Ketels, C.(2003) The cluster initiative greenbook (Stockholm: Ivory Tower).

Spencer, A., Kirchhoff, B. A., and White, C. (2008) "Entrepreneurship, Innovation, and Wealth Distribution: The Essence of Creative Destruction," International Small Business Journal 26(1): 9-26.

Stewart, D. (1794) Account of the life and writings of Adam Smith, LL. D: from the Transactions of the Royal Society of Edinburgh. 1794. Printed in the Collected Works of Stewart, V 10, 1-98.

Tierney, R., Hermina, W., and Walsh, S.T.(2013) "The Pharmaceutical Technology Landscape: A new form of technology roadmapping," Technological Forecasting and Social Change 80(2, Feb): 194-211.

Tierney, R., Groen, A.J., Harms, R., Luizink, M., Hetherington, D., Stewart, H., Linton, J. D., and Walsh, S.T.(2012) "Managing Highly FlexibleFacilities: An Essential Complementary Asset at Risk," International Journal of Enterprise Behaviour and Research 18(2): 233-55.

van der Valk, T. Moors,E., and Meeus, M. (2009) "Conceptualizing patterns in the dynamics of emerging technologies: The case of biotechnology developments in the Netherlands," Technovation 29(4): 247-64.

Von Hippel, E. (1986) "Lead Users: A source of Novel Product Concepts," Management Science 32(7): 791-805.

Wonglimpiyarat, J. (2006) "The dynamic economic engine at Silicon Valley and US Government programs in financing," Technovation 26(9): 1081-9.

Worldbank (2012) Definition of economic development, available at http://www.worldbank.org/depweb/english/ beyond/global/glossary.html\#19. 